\title{
TOŻSAMOŚĆ NA POGRANICZU. LUDNOŚĆ ROMAŃSKOJĘZYCZNA WSCHODNIEJ SERBII
}

\author{
EWA NOWICKA
}

\begin{abstract}
Identity on the borderland. Romance population of Eastern Serbia
The article concentrates on the analysis of ethnic identity of two romance groups living on the territory of Eastern Serbia: Vlachs and Cincars Aromanians).This area is a borderland, culturally, linguistically and politically; the situation significantly influences the ethnic identity choices of the two studied groups. The article is based on the data collected during three field studies: in 2015, 2016 and 2017. The author analyses in-depth interviews with Vlachs and Cincars, active in ethnic organizations and movements. Both aspects of the identity: psychological and behavioural are investigated, on one hand these aspects find expression in utterances, and on the other hand in behaviours and activities of both studied groups.
\end{abstract}

STRESZCZENIE. Artykuł koncentruje się na analizie tożsamości etnicznej dwóch grup romańskojęzycznych, zamieszkałych na obszarze wschodniej Serbii: Wlachów i Cincarów (Arumunów). Jest to obszar pogranicza kulturowego, językowego i politycznego, a sytuacja ta w różnym stopniu kształtuje etniczne samookreślenie dwóch badanych grup. Artykuł jest oparty na materiale terenowym, zebranym podczas trzech wyjazdów terenowych: w latach 2015, 2016 i 2017. Autorka analizuje wypowiedzi Wlachów i Cincarów, zaangażowanych w ruchy etniczne Autorka analizuje wypowiedzi Wlachów i Cincarów (Arumunów) zaangażowanych w działalność etnicznych organizacji i ruchów społecznych. Analizie poddane zostały oba aspekty etnicznej tożsamości: psychologiczny i behawioralny, z jednej strony wyrażające się w wypowiedziach, a z drugiej strony w zachowaniach i działalności członków obu badanych zbiorowości.

Autor: Ewa Nowicka, Collegium Civitas, Institute of Sociology, Defilad square 1, 00-901 Warsaw, Poland, ewanowickarusek@gmail.com, ORCID iD: https://orcid.org/0000-0003-0170-0845

Słowa kluczowe: Wlasi, Cincarzy, wschodnia Serbia, tożsamość

Keywords: Vlachs, Cincari, eastern Serbia, identity

Balcanica Posnaniensia. Acta et studia, XXV, Poznań 2018, Wydawnictwo Instytutu Historii UAM, pp. 297324, ISBN 978-83-65663-94-8, ISSN 0239-4278. Polish text with summaries in English and Polish.

doi.org/10.14746/bp.2018.25.16 
Motto:

One of the most topical, most complex and most important identical and political issues in the North-eastern Serbia is so-called 'The Vlach question'1.

\section{WSTĘP}

W artykule zajmę się tożsamością dwóch romańskojęzycznych grup etnicznych (czasem łączonych w jedną grupę), określanych jako Wlasi i jako Arumuni (po serbsku: Cincarzy), zamieszkujących obszar między doliną Timoku a doliną Morawy we wschodniej Serbii, nazywany Timoczką Krainą. Jest to terytorium ciągnące się od granicy z Bułgarią i Rumunią na zachodzie i północy a linią równoleżnikową biegnącą na północ od Niszu i na południe od Zajeczaru, a na zachodzie ograniczony rzeką Morawą. Artykuł jest oparty na antropologicznym badaniu terenowym przeprowadzonym w sierpniu 2015 r., w maju 2016 r. i w lipcu 2017 r. na terenie wschodniej Serbii ${ }^{2}$. Stosowałam przede wszystkim metody jakościowe, typowe dla antropologicznego badania terenowego: obserwację i swobodne wywiady niestandaryzowane. Wywiady zostały przeprowadzone z działaczami etnicznych organizacji i instytucji lokalnych, pracownikami kultury, a także osobami zaangażowanymi w regionalny ruch folklorystyczny, w tym regionalne zespoły artystyczne. Metoda kuli śniewej doprowadziła mnie także do osób, które można określić jako przeciętnych mieszkańców regionu.

Moim celem było poznanie i zrozumienie różnorodności i struktury tożsamości etnicznej romańskojęzycznej ludności wschodniej Serbii, na którą składają się w przewadze Wlasi, oraz pojedyncze rodziny także romańskojęzycznych Arumunów (Cincarów). Na badanym terytorium 154 wsie zamieszkują w znakomitej przewadze Wlasi, wśród których pojedynczo mieszkają Arumuni .

Zadaniem, które sobie postawiłam, było wykrycie typów tożsamości wlaskiej i arumuńskiej oraz ich - jak się okazało odmiennych - cech składowych na badanym obszarze. W tym celu badałam zarówno aspekt psychologiczny jak i behawioralny tożsamości etnicznej, przejawiający się z jednej strony w wypowiedziach osób należących do obu zbiorowości, a z drugiej strony w zachowaniach członków tych grup.

Tożsamość będzie tu rozumiana jako posiadane przez podmiot wizje własnej osoby, tego, co specyficzne dla autocharakterystyki. Są to cechy wskazywane przez podmiot w samoopisie jako istotne. Każde samozaliczenie, a także kategoryzacja przynależności do grupy przez osoby spoza niej, prowadzi do eksponowania wybra-

${ }^{1}$ Д. Крстић, Д. Коковић. Два звоника, а иркве нема: једна савремена драма о религији,политищи и етничком идентитету Влаха, w: Људи из пограничја говоре, red. М. Тасић, Д. Здравковић, Д. Крстић, Врање 2013, s. 263-296.

${ }^{2}$ Badanie było prowadzone w ramach projektu pt. Wolosi w europejskiej i polskiej przestrzeni kulturowej. Migracje - osadnictwo - dziedzictwo kulturowe, finansowanego przez Narodowy Program Rozwoju Humanistyki. 
nych różnic, tak jak są one postrzegane. W oglądzie obserwatora zewnętrznego może to być różnica niezauważalna, błaha, niewielka, nieistotna, ale w świadomości społecznej nabiera szczególnego znaczenia. Nawiązuję w artykule do koncepcji granic etnicznych Fredrika Bartha (1969), funkcjonujących w życiu społecznym. Są to odczuwane i praktycznie stosowane autodefinicje i definicje grupy własnej i grupy zewnętrznej. Fredrik Barth rozpoczął w ten sposób ważną tradycję rozumienia etniczności na gruncie nauki zachodniej, która rozwinęła się w tym zakresie co najmniej dwa pokolenia później niż w Polsce. Przyczyny polityczne sprawiły, że w polskiej tradycji socjologicznej i etnologicznej od lat 20. XX w. funkcjonowało pojęcie grupy etnicznej i narodu jako zbiorowości opartej na zjawiskach subiektywnych, świadomościowych, a nie obiektywnych (opartych na cechach „twardych”, o których istnieniu decydują naukowcy). Zgodnie $\mathrm{z}$ tą tradycją do grupy etnicznej należą ci, którzy na różne sposoby deklarują do niej przynależność, a zarazem są klasyfikowani przez innych jako odrębna zbiorowość. Zawsze ustalenie własnej tożsamości narodowej/etnicznej służy odnalezieniu swojego miejsca w świecie, zdefiniowaniu granic dzielących „swoich” i „obcych”. Będzie mnie interesowało jak współcześni Wlasi i Arumuni, zamieszkujący wschodni obszar graniczny Serbii, manifestują swój patriotyzm lokalny, regionalny i krajowy oraz swoją specyficzną tożsamość mniejszościową, czasami budującą się w opozycji do władzy centralnej Serbii. Zaznaczyć zarazem trzeba, że ani w historii, ani współcześnie nie można wskazać na żadne głębsze konflikty między ludnością romańskojęzyczną i ludnością serbską. Dotyczy to również poziomu państwowego ${ }^{3}$

\section{OBSZAR BADAWCZY: ETNICZNA RÓŻNORODNOŚĆ I WSPÓLNOTA}

Terytorium doliny Timoku - Timoczka Kraina - to obszar pograniczny w sensie politycznym: stykają się tu granice państwowe Serbii (kiedyś Jugosławii), Rumunii i Bułgarii. Stykają się tu też granice kulturowe tych trzech narodów (Serbów, Rumunów i Bułgarów), ale także grup żyjących wewnątrz jako mniejszości ${ }^{4}$ Tworzą się kulturowe i świadomościowe formy przejściowe, a poszczególne grupy etniczne muszą budować swoją tożsamość przez odniesienie do tożsamości innych grup - sąsiadów, konstruując różne wersje swojskości i obcości ${ }^{5}$. Podkreślić trzeba, że na omawianym obszarze, podobnie jak na całym półwyspie Bałkańskim, odmienności kulturo-

\footnotetext{
${ }^{3}$ Znamienne jest, że w pracy zbiorowej na temat konfliktów na Bałkanach ani Wlasi, ani Arumuni w ogóle się nie pojawiają. Zob. A. Koseski, Bałkańskie konflikty etniczne na przełomie XX $i$ XXI stulecia, w: Bałkany. Etnokulturowe podłoże konfliktów, red. W. Konarski, A. Koseski, Warszawa 2006, s. 93-120.

${ }^{4}$ Por. M. Tanty, Bałkany XX wieku. Dzieje polityczne, Warszawa 2003.

5 Por. E. Nowicka, Swojskość i obcość jako kategorie analizy socjologicznej, w: Swoi i obcy, red. E. Nowicka, Warszawa 1990.
} 
we dzielące różne grupy etniczne nie są wielkie ${ }^{6}$ Sprawia to, że ich tożsamość musi być konstruowana wokół starannie wyselekcjonowanych szczegółów i aspektów ich historii i tradycji. Wspólnota kulturowa bałkańska jest powszechnie odczuwana. Formy kultury artystycznej np. muzyki, wzornictwa strojów, które przez miejscowych są rozróżniane i identyfikowane jako serbskie, wlaskie lub macedońskie, są zarazem wszystkim znane i lubiane. Na przykład Serbowie deklarują, że lubią wlaską muzykę, a Wlasi serbską .

W badanym regionie tożsamość lokalna, polityczna, kulturowa, historyczna nie dostarczają wyraźnych linii podziału grup etnicznych. Uczeni serbscy twierdzą, że kultura całych Bałkanów jest, mimo różnorodności etnicznej mieszkańców, w gruncie rzeczy w znacznym stopniu jednolita. W związku z tym mówić możemy o istnieniu zjawiska kultury bałkańskiej, która jest mieszaniną cech słowiańskich, greckich i romańskich, nie licząc wpływów tureckich. Ten mieszany charakter odbija się w kulturze materialnej, w języku, w toponomastyce. Wlasi z rejonu Timoku w swoich gwarach lokalnych mają dużo elementów słowiańskich, ponieważ wszyscy żyli w taki sam sposób, używając tego samego zestawu przedmiotów kultury materialnej jak np. ubiór, sprzęty domowe, narzędzia pracy. W efekcie spotykamy nazewnictwo miejsc w obu językach - serbskim i wlaskim. Różne formy zabawy, wesela, obrzędy miały (i do tej chwili mają) podobny charakter, który możemy określić jako bałkański w stylu. Nawet muzyka, która się u Słowian i romańskojęzycznych mieszkańców nieco różni, jednak ma cechy wspólne: podobne instrumenty muzyczne i pewne charakterystyczne cechy stylu gry. Etnologowie serbscy podkreślają ogólną bałkańską wspólnotę kulturową, górującą nad etnicznymi odmiennościami. Mimo to każda z grup etnicznych powołuje się właśnie na swoją kulturową specyfikę jako na argument na rzecz uznania jej odrębnej tożsamości. Dzisiejsza różnorodność kulturowa badanego obszaru jest efektem długotrwałych, czasem gwałtownych przemian kulturowych, migracji, przeobrażeń politycznych. Można przyjąć uogólniające stwierdzenie, że na południe od Dunaju i Sawy przez długie stulecia następowało coraz silniejsze wnikanie grup słowiańskojęzycznych na obszary romańskojęzyczne. Stopniowo następowało mieszanie się grup etnicznych aż do stanu dominacji Słowian. Ludność romańskojęzyczną tego terytorium stanowią obecnie mniejsze lub większe enklawy pozostałe po dawnej ludności przedsłowiańskiej. Natomiast na północ od Dunaju proces miał kierunek odwrotny - dominującą stroną stopniowo stawała się ludność romańskojęzyczna, choć także następowało mieszanie się tych dwóch elementów kulturowych. I na tym terytorium powstał rumuński naród, a także rumuńskie państwo. Jednak nie bez przyczyny na Bałkanach i w Rumunii nazewnictwo związane z pasterstwem i owcami jest romańskie, a z rolnictwem jest słowiańskie. Dotyczy to także przedmiotów codziennego użytku.

\footnotetext{
${ }^{6}$ Podzielam opinię serbskiego etnologa Dejana Krstića; por. Д. Крстић и Д. Коковић. Два звоника, а иркве нема: једна савремена драма о религији,политици и етничком идентитету Влаха., w: Људи из пограничја говоре, red. М. Тасић, Д. Здравковић, Д. Крстић, Врање 2013, s. 263-296.
} 
Wśród etnicznych zbiorowości zamieszkujących Serbię, poza grupami cygańskimi (zaliczanymi do różnych grup etnicznych), przeważają zbiorowości słowiańskojęzyczne: Macedończycy, Bośniacy, Torlacy, Szopowie. Inną kategorię stanowią dwie romańskojęzyczne grupy: Wlasi i Arumuni, którzy wzajemnie postrzegają się jako grupy odrębne, ale językowo spokrewnione. Języki arumuński i wlaski z doliny Timoku należą do jednej grupy i są w znacznym stopniu do siebie podobne, tak jak polski $i$ serbski $(2016, \mathrm{DK})^{7}$. Jedni i drudzy zauważają, a nawet podkreślają swoją odrębność, mimo że w praktyce ich życie nie różni się w chwili obecnej. Wlasi na badanym obszarze stanowią znakomitą większość wśród ludności romańskojęzycznej. Akcentują przy każdej okazji swoją rdzenność, podczas gdy Arumuni są nieliczną, rozproszoną zbiorowością przybyłą głównie w XIX w. i zajmującą zwykle ekonomicznie uprzywilejowane miejsce w całym społeczeństwie wschodniej Serbii. Deklaracje wlaskiej przynależności etnicznej pojawiły się w spisie powszechnym w 2002 r, a sytuację wlaskiej mniejszości uregulowała ustawa z roku $2006^{8}$ r. Od tej pory mają oni status mniejszości etnicznej w ramach społeczeństwa serbskiego, wspierani jako mniejszość ze strony państwa. Mają też oficjalne przedstawicielstwo w parlamencie w postaci Narodowej Rady Wlachów (Nacionalni Savet Vlaha). Wśród społeczeństwa serbskiego opisywani są jako grupa szczególnie konserwatywna lub co najmniej tradycjonalistyczna, zachowująca swoją archaiczną kulturową odrębność. Do niedawna trwanie przy tradycji odbywało się w społecznościach wlaskich raczej poprzez nawykowe, mechaniczne trzymanie się kulturowych wzorów przodków niż poprzez świadomy wybór ideologiczny.

Natomiast Arumuni, o wiele mniej liczni, nie posiadają na terenie Serbii statusu odrębnej mniejszości etnicznej. Ostatni spis podał w Serbii liczbę 320 osób, które się jako Cincarzy zadeklarowali, co nie wystarczyło, aby się ubiegać o status mniejszości etnicznej. Liderzy tej grupy jednak wskazują, że kiedy powstało stowarzyszenie Arumunów - Lunjina w początkach lat 90. ubiegłego stulecia - w samym Belgradzie więcej niż 320 osób zadeklarowało tożsamość arumuńską ${ }^{9}$ Arumuni na obszarze całej Serbii są zbiorowością w dużym stopniu zurbanizowaną, aspirującą do miana elity finansowej i intelektualnej. O tej odmiennej sytuacji obu grup romańskojęzycznych decyduje społeczna historia obszaru - bardzo długo utrzymujący się charakter lokalnych,

${ }^{7}$ Ten typ zapisu (2016, DK) odnosi sią do wywiadu, wskazuje na rok jego przeprowadzenia i fikcyjne inicjały rozmówcy. W tekście artykułu znajdują się następujące sygnatury, odnoszące się do poszczególnych wywiadów: 15 MB; 16 B; 16 DB; 16 DD; 16, DF, 16 DK; 16 DP; 16, Grljan; 16 Miomira; 16 MK; 16 N; 16 NO; 2015, DD; 2015, A; DD1; 2016 DF; 2016 DP; DF 2016; DP 2016; D.P. 2016, M 2016; Milica 2016; 2016, Negotin; 2016, Zajeczar; Prvulović 2016.

${ }^{8}$ Art. 2 Ustawy o ochronie praw i wolności mniejszości narodowych, Устав Републике Србије. 2006, http://www.parlament.gov.rs/upload/documents/Ustav_Srbije_pdf.pdf [dostęp 03.07.2018].

${ }^{9}$ Liczebność grupy podawana w spisach powszechnych jest istotnym czynnikiem rozwoju grup etnicznych. poprzez ukazanie istnienia i liczebności pewnych grup, co stało się dla ich liderów inspiracją do rozwoju tożsamości grupowych i mobilizacji politycznej; por. S. Łodziński, Etniczność i jej miary. Przypadek pytań „etnicznych” w Narodowym Spisie Powszechnym Ludności w Polsce w 2011 roku, w: Antropologiczne inspiracje. Księga Jubileuszowa dla profesor Ewy Nowickiej, Warszawa 2013. 
zamkniętych zbiorowości wlaskich. Bez zastrzeżeń możemy opisywać je przy użyciu typologicznych określeń klasyków socjologii: solidarność mechaniczna (Durkheim), społeczności typu gemeinschaft (Tonnies), społeczeństwo sakralne (Becker). Te kategorie teoretyczne natomiast zupełnie nie nadają się do opisu Arumunów (Cincarów), którzy szybko, jeszcze w końcu XVIII w. stawali się ludnością miejską, kupiecką, rzemieślniczą, dobrze się adaptującą do współczesnej cywilizacji. Początkowo (wiek XVIII i XIX) ci najbogatsi arumuńscy kupcy, którzy się osiedlili w miastach przyjęli, odbierany jako prestiżowy, sposób życia ówczesnej warstwy wyższej czyli Turków, zaznaczając w ten sposób swoją odmienność od wiejskich, pasterskich przodków. Do połowy XIX wieku styl turecki wśród serbskich Arumunów ciągle dominował. Stan ten trwał do czasu wojen serbskotureckich $1878-79$, kiedy to Turcy utracili poważną część władzy nad Serbią. Wtedy to dzieci bogatych kupców arumuńskich zaczęły się kształcić w miastach zachodniej Europy. Zarówno w stroju jak i architekturze stopniowo przejmowano styl europejski.

\section{ROZWÓJ STOSUNKÓW SPOŁECZNYCH WSCHODNIEJ SERBII}

Historia obszaru wschodniej Serbii jest, co na Bałkanach nie jest zaskakujące, niezwykle złożona. W roku 1830, po uzyskaniu względnej autonomii przez Serbię w ramach imperium osmańskiego, obszar doliny Timoku, zamieszkiwany w znacznym stopniu przez ludność wlaską wszedł w ściślejszy zasięg wpływów serbskich. Obszar ten zawsze miał charakter marginalny, co moi wlascy rozmówcy obecnie podkreślają, nadając tym konstatacjom charakter ideologiczny. Twierdzą, że podobnie jak serbscy władcy w XIX w., tak i dzisiejsi serbscy politycy w Belgradzie nie zajmują się tym obszarem. .Wlascy liderzy ubolewają nad tym, jak to w czasach wojen tureckich 1876-1878 tereny te zostały wyniszczone, czego efektem był bunt miejscowej ludności (w domyśle - Wlachów) przeciwko serbskiej władzy ${ }^{10}$.

Jednym z najważniejszych wątków historycznych wykorzystywanych w sporach międzyetnicznych jest uczestnictwo Wlachów w walkach o niepodległość najpierw przeciw Turkom, a potem przeciw Niemcom. Wlasi i Arumuni byli aktywnie zaangażowani w ruchy wyzwoleńcze, które doprowadziły do likwidacji władzy otomańskiej na Bałkanach, a także w ruch oporu podczas drugiej wojny światowej. U arumuńskich działaczy pojawia się nawet twierdzenie, że to ich przodkom można zawdzięczać wyzwolenie Grecji od władzy tureckiej. Swoje zasługi wobec Serbii podkreślają nieodmiennie wszyscy moi wlascy rozmówcy. Zasługi te przeciwstawiane są lekceważeniu ze strony Belgradu (2015 DD, 2016 DP, DD1).

Na rozwój stosunków etnicznych miał gwałtowny proces industrializacji terenu wokół Majdanpeku (kopalnie miedzi, złota, srebra i żelaza) oraz Boru (kopalnie

${ }^{10} \mathrm{~W}$ literaturze historycznej opis tych wydarzeń jest o wiele bardziej skomplikowany i słabo się wiąże z podziałami etnicznymi. por. M. Tanty, Bałkany XX wieku. Dzieje polityczne, Warszawa 2003. 
miedzi). Przyniosła ona intensywną urbanizację terenu, większość wlaskich wsi wokół Brestowaca stała się częścią terenu uprzemysłowionego. Mieszkańcy porzucili swój pasterski i rolniczy tryb życia, stając się górnikami. Od XIX w. dotąd izolowana wlaska ludność weszła w kontakt $\mathrm{z}$ licznymi narodami. W wywiadzie burmistrz Majdanpeku wymienia 23 narodowości wśród mieszkańców miasta $(16,56)$. Byli to wykwalifikowani robotnicy z zagranicy, którzy przybyli w celu budowania przemysłu na obszarze wokół złóż naturalnych. Ostatnie dekady (po 1990 r.) zaznaczają się w okresie po rozpadzie Jugosławii upadkiem przemysłu wydobywczego w okolicy oraz intensywną emigracją ekonomiczną do Niemiec, Austrii, Włoch i innych krajów Zachodniej Europy. Zmiany ekonomiczne doprowadziły do głębokich przemian społecznej struktury obszaru, który podlegał już wcześniej poważnym przeobrażeniom wraz z przechodzeniem znacznej części ludności na osiadły tryb życia. Unaoczniają to dzisiejsze różnice (i wzajemne wizerunki) dzielące dwie zbiorowości wschodnioserbskich Wlachów: Ungurianów i Caranów..

Obszar między Timokiem i Morawą manifestuje jako całość swoją kulturalną odrębność. Mieszkańcy są świadomi swojego położenia geograficznego na krańcach państwa serbskiego, w sąsiedztwie Rumunii i Bułgarii. To położenie ma ogromny wpływ na wewnętrzne spory wśród wlaskich liderów i wlaskiej inteligencji, wpływając zarazem na tożsamościowe wybory. Oddziałuje również na kształtowanie się ruchów politycznych i organizacji oddolnych.

Kolejno przedstawię sytuację społeczną i wybory tożsamościowe obu grup romańskojęzycznych obszaru wschodniej Serbii: Wlachów i Arumunów (Cincarów). Podział na Wlachów i Arumunów jest obecny w świadomości mieszkańców, ale dla wielu z nich nie jest do końca jasny. Dušan Firović, który w ramach Narodowej Rady Wlachów (Nacionalni Savet Vlaha) ${ }^{11}$ w Zajeczarze jest odpowiedzialny za informację, opowiada, jak to kiedyś myślał, że Cincarzy $i$ Vlasi to jest jedno i to samo (DF 2016). W prostych słowach pokazuje podobieństwo sytuacji obu grup: Oni się zaczęli gubić tak jak my teraz zaczęliśmy się gubić (DF 2016). Lepiej wykształceni Wlasi akcentują szerszą wspólnotę, do której należą i Wlasi i Arumuni. Natomiast wśród Arumunów częste jest odżegnywanie się od jakichkolwiek związków z Wlachami, wyraźnie w poczuciu własnej wyższości. Jednak arumuńscy naukowcy nie mają wątpliwości co do bliskości historycznej i językowej obu grup.

11 Nacjonalny Savet Vlacha jest to państwowa instytucja, ciało wybierane podczas wyborów. Tylko osoby, które się zadeklarowały oficjalnie jako Wlasi, mogą wybierać władze Rady. Dla aspirujących do pozycji oficjalnych działaczy Rady ważne staje się oddziaływanie na deklaracje wlaskiej tożsamości we własnym otoczeniu. Państwo przyznaje dotacje budżetowe lokalnym oddziałom Rady.. Istotą działalności Narodowej Rady Wlachów jest, jak to formułuje szef lokalnej administracji w Majdanpeku, sprawić, żeby ludzie nie zapomnieli swojej tożsamości. Tak jak w przypadku każdej mniejszości narodowej utrzymać swoją kulturę, język, gwarę, zachowanie tożsamości grupy. 


\section{WLASI: UNGURIANIE I CARANIE}

Zarówno w literaturze etnograficznej, jak i w życiu codziennym populacja Wlachów wschodniej Serbii dzielona jest na dwie grupy kulturowe: Ungurianie i Caranie (czasem też nazywani Kympianie). Pierwsza grupa jest historycznie związana z falą migracji pasterzy z Banatu na teren wschodniej Serbii, w okresie od 1718 do 1739 r., w czasach władzy imperium Habsburgów (z tzw. Hungarii). Wtedy monarchia Habsburska panowała nad wschodnią Serbią, nad Banatem i Oltenią. W wyniku Pokoju Belgradzkiego w 1739 r. Habsburgowie musieli opuścić Serbię i Oltenię, a na obszarach tych przywrócona została władza Turcji. W rękach Habsburgów pozostał tylko Banat. Obecnie Ungurianie są przedstawiani przez moich wlaskich rozmówców jako ruchliwi pasterze z górskich terenów wschodniej Serbii. Ich obecny stereotyp wśród Caranów oraz wśród miejscowych Serbów wskazuje na takie cechy jak brak wykształcenia i ubóstwo. Podkreśla się też różnice między Ungurianami i Caranami w charakterze tradycyjnego stroju. Jak mówi Milica, Ungurianie nosza na głowach wetniane czapki, białe i spodnie, wszystko białe z wetny, a Caranie czyli Campianie mają czarne czapki i spodnie. Opisy te odnoszą się do stroju historycznego i cech historycznych, dziś trudnych do przypisania komukolwiek.

Caranie (pochodzenie słowa od wołoskiego cara, łacińskie terra - ziemia) są opisywani jako bogatsza ludność rolnicza, posługująca się zaawansowaną technologią wyrobu bogatych, haftowanych strojów, uprawiająca zaawansowaną gospodarkę rolniczą na żyznych równinach wzdłuż Dunaju i wokół Negotinu. Byli zapewne starszą warstwą ludnościową, związaną z migracjami z północy, spoza Dunaju, ale też być może z dawnymi, rdzennymi mieszkańcami. Dopiero od lat 20. XX wieku, wraz z postępem cywilizacyjnym, zaczynają się zacierać różnice poziomu życia, statusu i stylu ubiorów między Ungurianami i Caranami. W niektórych wsiach unguriańskich (np. Crnajka) członkowie miejscowego zespołu folklorystycznego dumni są, że z carańskiego Negotina przyjeżdżają artyści ludowi właśnie do nich uczyć się choreografii i tradycji (2015, A). Wypowiedzi takie implicite zawierają dawny stereotyp i są sposobem pozbywania się poczucia niższości przez Ungurianów. Podkreślają, że to właśnie u Ungurianów kobiety noszą piękne suknie z większą gamą kolorów. Mimo to do dziś jednak akcentowane są różnice między jeszcze do niedawna ruchliwymi górskimi Ungurianami i osiadłymi od dawna rolniczymi Caranami.

Tych ostatnich nazywa się też nazwą Campianie (czyt. kympnianie) od rumuńskiego i wlaskiego słowa pole. Równocześnie zacierają się między nimi różnice społeczne. Ród był znacznie dłużej podstawową jednostką organizacji społecznej wśród mobilnych Ungurianów niż wśród osiadłych Caranów. Dlatego u nich daje się zauważyć wyższy poziom kulturowego synkretyzmu niż u Ungurianów. ${ }^{12}$ Podział na te dwie grupy etnograficzne jest wśród Wlachów ciągle żywy społecznie; każdy Wlach

12 M. Luković, Sezonowe migracje pasterzy na Bałkanach: charakter, historia, transformacje, „Res Historica", 2016, nr 40, s. 61. 
wie, kto jest Ungurianem a kto Caranem, która wieś jest zaludniona przez przedstawicieli jednej, a która drugiej grupy. Rozróżnienie dotyczy też dialektu. Sami thumaczą badaczowi, że unguriański dialekt jest miękki olteński, podczas gdy ten którym mówią Caranie twardy. Unguriańska palatalizacja wyraża się w podawanych mi przykładach wymowy: szczi rumuniesztie, podczas gdy w carańskim - szti rumuneszte. Caranie mówią cze facze, a ungurianie szie faszie. Wskazuje się też na wymowę dźwięku dz - buna dziła u Ungurianów i buna ziła u Caranów ${ }^{13}$. Jednak dziś można też usłyszeć, że ci koło Negotinu i koło Niszu to jest jeden naród tylko rzeka przedzielony. (16 DP). Obie gwary są wzajemnie zrozumiałe. Obie grupy mają swoich etnograficznych pobratymców za granicami państwa serbskiego. Również w okolicach Widinu w Bułgarii mieszkają zbliżone grupy do Caranów.

Wioski unguriańskie są mniejsze i bardziej rozproszone w porównaniu do carańskich, gdyż Ungurianie żyją na terenach górskich i tradycyjnie prowadzili gospodarkę pasterską. W okolicach Zajeczaru, który w zasadzie zaznacza południową granicę zasiedlenia ludności wlaskiej, obok siebie położone są wioski unguriańskie i carańskie. W wielu wsiach na tym terenie jednak ciągle mówi się po wlasku w życiu codziennym ${ }^{14}$. Wiedza o tym, które wioski są wlaskie jest absolutnie powszechna. Mieszkańcy wiosek podkreślają wlaski charakter miejscowej toponomastyki, wyjaśniają pochodzenie nazw: Dżerdap = zimna woda, Dzianovac pochodzi od zimnych wiatrów, bo wieś położona jest na górce, nazwa Korowlasz pochodzi od dźwięków przypominających organy (tak wiatr gwiżdże przez pobliskie skały) - tak brzmia żatobne śpiewy, bo tam zginęło wielu ludzi w czasach tureckich (Milica 2016).

Spór o liczbę wlaskiej ludności dotyczy zarówno wsi jak i miast. Liderzy wskazują na absurdalność danych spisowych. Według spisu powszechnego w Serbii w $1953 \mathrm{r}$. 198701 osób wskazało język wlaski jako język ojczysty (maternyj jezyk). Zarazem w tym samym spisie zaledwie 27000 osób określiło się jako Wlasi, zaś reszta 169000 - jako Serbowie. Nie jest jednak możliwe, że taka liczba etnicznych Serbów znało język wlaski i deklarowało jego znajomość jako języka ojczystego ${ }^{15}$.

Jak zwykle dane spisowe nie są dokładne w przypadku deklaracji przynależności etnicznej. Zwykle jest tak z powodu sytuacji mniejszości, która często stara się zatrzeć swoją mniejszościową przynależność. Zatem liderzy lokalnych wlaskich organizacji mówią w wywiadach o znacznie wyższych liczbach w porównaniu $\mathrm{z}$ deklaracjami spisowymi ${ }^{16}$ Dušan Firović z Narodowej Rady Wlachów twierdzi, że od Zajeczaru do Pożarewaca i do Dunaju wzdluż doliny Timoku, to wszyscy sq Wlasi.

${ }^{13}$ Wszystkie zapisy podaję w wersji fonetycznej.

${ }^{14}$ Wymieniane są: Grljan, Gamzigrad, Nikoliczevo, Lubnica, Szliwar Prolita, Dubuczan i Goworica.

${ }^{15}$ Podobna sytuacja zachodzi w przypadku Romów w spisie powszechnym z 2011 r. S. Łodziński, K. Warmińska, G. Gudaszewski, M. Szmeja, Mniejszości narodowe i etniczne w Polsce, op. cit.

${ }^{16}$ Jest to znana regularność w wielu krajach np. w Polsce. (por. L. Adamczuk, S. Łodziński, Mniejszości narodowe $w$ Polsce, op. cit. W przypadku wszystkich mniejszości dane są notorycznie zaniżane w spisach powszechnych. 
Tabela 1. Deklaracje tożsamościowe w wybranych miastach i okręgach wschodniej Serbii według spisu powszechnego z $2011 \mathrm{r}$.

\begin{tabular}{|l|c|c|c|}
\hline \multicolumn{1}{|c|}{$\begin{array}{c}\text { Nazwa } \\
\text { miejscowości }\end{array}$} & $\begin{array}{c}\text { Liczba osób } \\
\text { deklarujących } \\
\text { narodowośc wlaską }\end{array}$ & $\begin{array}{c}\text { Liczba osób } \\
\text { deklarujących } \\
\text { narodowość rumuńską }\end{array}$ & $\begin{array}{c}\text { Ogólna liczba } \\
\text { mieszkańców }\end{array}$ \\
\hline Negotin & 3382 & 274 & 37056 \\
Kladovo & 788 & 156 & 20635 \\
Bor (miasto) & 6701 & 269 & 48615 \\
Bor (okręg) & 13313 & 791 & 59461 \\
Zajeczar (miasto) & 2856 & 204 & 119967 \\
Zajeczar (okręg) & 6254 & 307 & 17610 \\
Veliko Gradiszte & 352 & 65 & 15516 \\
Kuczewo & 3927 & 105 & 31259 \\
Petrovac & 4609 & 217 & 75334 \\
Pozarevac & 177 & 91 & 183625 \\
Braniczevo (okręg) & 13238 & 728 & 214536 \\
Okręg Pomoravski & 1938 & 250 & \\
\hline
\end{tabular}

Czasem 60\%, czasem 70\%, ale czasem więcej. Rozbieżność z wynikami spisu thumaczy spadkiem zainteresowania własną etniczną tożsamością: Ale wszystko się rozplywa. I gdyby nie decyzja Rady Europy, wszyscy całkiem zgubilibyśmy się (DF 2016).

\section{ARUMUNI (CINCARZY)}

Historia mówi, że Arumuni po tym, jak porzucali swój pierwotnie pasterski tryb życia, już dziesiątki, a nawet setki lat temu zostawali kupcami, rzemieślnikami, właścicielami drobnych przedsiębiorstw, kawiarni, restauracji, hoteli. Następnie, dzięki naciskowi jaki kładli na wykształcenie dzieci, wchodzili do elit społeczeństwa serbskiego ${ }^{17}$ Obecnie większość serbskich Arumunów to inteligencja: lekarze, nauczyciele, pracownicy kultury, poeci, naukowcy, politycy.

We wschodniej Serbii Arumuni są nieliczni. Jak dziś wspominają, pojedyncze rodziny lub grupy rodzin w przeszłości (koniec XVIII w. i XIX w.) przybyły do miast $\mathrm{i}$ wiosek tego etnicznie mieszanego obszaru, kończąc tu zwykle swoją migrację z Albanii i Grecji via Macedonia i południowa Serbia. Tożsamość Arumunów, jak wszędzie, jest skonstruowana wokół rodzinnych historii, a także wokół ich dawnego i współczesnego wysokiego statusu społecznego i ekonomicznego. Ich integracja ze zbiorowościami, w których się osiedlali, często polegała na asymilacji pojedyn-

${ }^{17}$ Por. D. J. Popović, O cincarima: prilozi pitanju postanka naseg gradanskog drustva, 1937. 
czych rodzin lub małych grup rodzin. Stopniowo tracili dystynktywne cechy kulturowe - własny język (specyficzny romański dialekt) i obyczajowość. Większość moich arumuńskich rozmówców w Belgradzie, w Serbskim Stowarzyszeniu Cincarów Lunjina bardzo silnie podkreślała swoją odrębność od wschodnioserbskich Wlachów, a niektórzy wręcz odcinają się od swojego pochodzenia - od pasterskich przodków. Wypierają się tradycji i deklarują, że nie stworzyli i nigdy nie mieli żadnych specyficznych form muzycznych, tańców, strojów i ludowych obyczajów. Podkreślają w ten sposób swoją miejskość, a przez to wyższość nad pozostałymi romańskojęzycznymi mieszkańcami Serbii i innych obszarów bałkańskich. Jednakże w praktyce Arumuni, żyjąc pojedynczymi rodzinami wśród Serbów i Wlachów w serbskich miastach i wlaskich wioskach, integrowali się i czuli a nimi kulturową bliskość, a nawet pokrewieństwo. Przykładem mogą być arumuńskie (z pochodzenia) rodziny we wlaskiej wsi Krivelj i Brestovac (obsztina Bor). Historycy arumuńskiego pochodzenia podkreślają, że ich rodacy we wschodniej Serbii często się całkowicie asymilowali do populacji miejscowych Wlachów, a ich dzisiejsza kultura jest rezultatem mieszania się arumuńskich i lokalnych wlaskich tradycji (15 MB). Równocześnie, w niektórych przypadkach nawet nie pamiętają swoich korzeni, i kulturowych tradycji. Jednakże, nawet całkowicie zasymilowani do lokalnych form kultury wlaskiej, Arumuni w wioskach i miastach wschodniej Serbii mają poczucie własnej specyfiki. Podkreślają trudne do zauważenia przez zewnętrznego obserwatora różnice dzielące ich od miejscowych Wlachów, w tym również własną odmienność fizyczną. Jeden z wybitnych działaczy arumuńskich w Serbii zapytany o to czy można rozróżnić po wyglądzie Arumunów i Wlachów serbskich, odpowiedział w sposób powściągliwy, że nie było żadnych poważnych badań na ten temat, jest to jedynie rodzaj wiedzy potocznej (15 MB). Jednakże, inny członek arumuńskiej wspólnoty oznajmił, że bez wątpienia Arumuni sa fizycznie do rozróżnienia, różniąc się $w$ sposób widoczny od Wlachów. (16 B). Arumuni na różne sposoby manifestują swoje poczucie wyższości w odniesieniu do Wlachów wschodniej Serbii. Jedna z wykładowczyń uniwersytetu w Niszu posiadająca cincarskie pochodzenie akcentowała, że Cincarów można od razu poznać, twierdząc, że są od otoczenia jaśniejsi i niżsi (16 Miomira).

Są w znakomitej przewadze mieszkańcami miast, choć pojedyncze rodziny zostały wchłonięte przez społeczności wiejskie kiedyś parając się konkretnymi zawodami. Byli znawcami sztuki murarskiej, właścicielami młynów i sklepów wiejskich, na ogół różniąc się statusem ekonomicznym od pozostałych mieszkańców wlaskich $\mathrm{wsi}^{18}$. Status ten dał im podstawę do poczucia wyższości, nie tylko nad lokalną ludnością wlaską, ale też nad Serbami. Jeden ze wschodnioserbskich Arumunów tak pre-

18 Zajmowali się malowaniem i bieleniem oraz budowaniem domów z użyciem technologii gaszenia wapna i wstawiania metalowych umocnień. Domy takie można spotkać np. w Brestovacu i Krivelju. Prowadzenie kawiarni, wyrób ciastek, to była specjalność cincarska. Dziś wspomina się, że wszystkie kawiarnie na pewno mieli tylko Cincarzy (16 B). Dziadek rozmówcy też miał kawiarnię w Miliczewie. 
zentuje różnice między Arumunami i Wlachami: Wcześniej byli nomadami, prowadzili karawany z końmi kupieckie. Mieli taka cechę - kosmopolityzm, znali języki, sa tak wychowani, że moga się dobrze czuć i tu i w Nowym Jorku, szybko się wszędzie adaptowali. Cincarzy to jest naród, który się roztopit, którego juz nie ma, który tylko istnieje we fragmentach. Nie ma ich, nie ma... I zaraz dodaje: Oni nie narzekaja na swoja pozycje, nie złoszczq się. Oni przyszli przed Stowianami. Oni sq autentyczni na Batkanach. Oni i Grecy to sq autentyczne narody na Batkanach. A potem przyszli dzicy, Stowianie, dzicy, prości, spali w ziemiankach, prości, bez kultury, to oni zniszczyli rzymskie cesarstwo - barbarzyńcy. (16 B). Jest to wypowiedź wykształconego Arumuna, od pokoleń zamieszkałego w małym mieście wschodniej Serbii. Jak widać ubolewaniu nad rozpadem niegdyś wielkiego narodu towarzyszy przekonanie o bezwzględnej wyższości jego rozproszonych potomków. Do dziś towarzyszy ono świadomości bliskości lingwistycznej z Wlachami, zauważalnej w otoczeniu serbskojęzycznym. Mój arumuński rozmówca z Niszu, historyk z wykształcenia, twierdzi, że Wlasi i Arumuni zaczęli się różnić od siebie już w Średniowieczu. Arumuni zaczerpnęli, przejęli wiele cech kulturowych i elementów leksyki od Greków, gdyż język grecki byt rodzajem lingua franca w kontaktach handlowych na Batkanach. (16 NO). Rozmówca przyznaje, że Arumuni siebie sami traktują jako elita, z powodu znajomości wielu języków: byli tłumaczami, politykami, właścicielami hoteli i banków. Równocześnie akcentuje to, że najwcześniejsze teksty po arumuńsku zostały opublikowane już na początku wieku XVIII.

\section{TOŻSAMOŚĆ ARUMUNÓW}

Moi arumuńscy rozmówcy bezwyjątkowo koncentrowali się na własnej genealogii, historii rodzinnej, pozycji przodków. Ich etniczna tożsamość znajduje oparcie w wiedzy o przeszłości rodzin, podtrzymywanej pamięci swojego pochodzenia i szacunku dla przodków. Dejan Blagojević z Miniceva jest autorem wystawy fotograficznej Cincars from Timok Valley (Cincari sa Timoka), która otwarta została 5 września 2013 roku w Archiwum historycznym (Istorijski Arhiv) w Zajeczarze. Jest to wystawa fotografii, pokazująca historię i powiązania rodzin arumuńskich i ich losów. Autor ma nadzieję, że wystawa będzie też pokazywana za granicą - w Bułgarii w Dupnicy, gdzie żyje wspólnota arumuńska. Autor wystawy twierdzi, że dla ustalenia indywidualnej tożsamości każdego Arumuna konieczna jest odpowiedź na pytanie: „Z jakiej jesteś wioski? " i każdy odpowie: „, z Kruszewa, z Magarewa, z Gopeszu”. Odpowie od razu! Jest to sprawa oczywista i ważna dla każdego Arumuna. Pozostają także w bliskim ze sobą kontakcie, znają swoje nazwiska i miejsca zamieszkania. Arumuni zawsze pozostaja w kontakcie z innymi Arumunami - podkreśla wykładowca na wydziale prawa uniwersytetu w Niszu (16 MK). Mając, jak to obecnie akcentują, wysoką pozycję społeczną już od XIX w. Arumuni mogli wpływać intensywnie na kształt powstającej jako nowoczesne państwo Serbii. Pod wieloma względami, jak sami twierdzą w wy- 
wiadach, byli podobni do Żydów. Również nie negują, że zawsze Arumuni byli w dobrych relacjach z imperium tureckim i jego administracją. Byli oni przydatni władzy otomańskiej ze względu na szerokie międzynarodowe i międzykulturowe kontakty oraz najomość wielu języków..

Arumuńscy intelektualiści w wywiadach zdecydowanie odwoływali się do swojej odrębności od Rumunów. Nawet ci, którzy akceptują związki z Rumunami, odrzucają klasyfikowanie ich jako grupę etniczną w obrębie narodu rumuńskiego. Zdarzało się już w końcu XIX w., że Arumuni bardzo zdecydowanie się od takiej wspólnoty odżegnywali. Rozmówca z Miniczewa stwierdza zdecydowanie: Ale my mówimy: nie jesteśmy Rumunami. My jesteśmy Armani (16 DB). Arumuński działacz krytycznie odnosi się do europejskiej nauki na temat tej grupy, w tym przede wszystkim do twórczości Gustawa Weiganda: A rumuńska propaganda finansowała Weiganda, dostał pieniądze, i choć wiedział bardzo dużo, tak mówit jak oni [Rumuni - EN] chcieli. Rumun i Arman brzmi podobnie, ale te asocjacje nie sa trafne. Termin „Arman” oznacza tylko Cincara. (16 DB).

Arumuńscy rozmówcy wyrażali stosunkowo niewielkie zainteresowanie innymi romańskojęzycznymi mieszkańcami Serbii. Z rzadka podkreślali swoje pokrewieństwo z Wlachami, rzadko wskazywali na ich podobieństwo, częściej Wlachów ignorowali, czasem podkreślali nawet głębokie różnice dzielące ich od Wlachów. To Wlasi częściej od Arumunów akcentowali wspólnotę językową i kulturową, etniczną. W jednym obie grupy się zwykle zgadzają; na ogół Arumuni i Wlasi odrzucają swoją etniczną identyczność z narodem rumuńskim.

\section{FORMY WYRAŻANIA SIĘ TOŻSAMOŚCI WLASKIEJ}

U obu badanych grup romańskojęzycznych - Wlachów i Arumunów - odmiennie przejawia się ich etniczna tożsamość. Tożsamość Wlachów we wschodniej Serbii jest kształtowana przez kilka czynników związanych z terytorialnym położeniem zbiorowości. Jednym z nich jest wielopokoleniowa przynależność do państwa serbskiego. Sprawiał on, że interesy polityczne wiązały od stuleci Wlachów z Serbami przede wszystkim jako ludność chrześcijańską wobec muzułmańskiego imperium osmańskiego. Wlasi, w tym czasie żyjący na lewym brzegu Dunaju, znajdowali bezpieczne i dogodne schronienie przed tyranią swoich lokalnych władców uciekając na tereny państwa serbskiego.

Drugi czynnik stanowi bliskość przestrzenna państwa rumuńskiego, w którym język państwowy, mówiony w różnych wersjach dialektalnych przez znakomitą większość ludności posiada cechy bliskie zróżnicowanym gwarom wlaskim na terenie Serbii. Uformowanie się państwa rumuńskiego w 1862 r. rozpoczęło nowy etap w historii romańskojęzycznej ludności Bałkanów. Władze rumuńskie przekonywały ludność tę o jej wspólnocie z narodem rumuńskim, wzbudzały przekonanie o politycznej przynależności do państwa rumuńskiego. 
Trzeci czynnik, polityczny, związany jest z ogólnoświatową, i szczególnie obecną w ostatnich dziesięcioleciach w Europie tendencją do przyznawania wartości różnorodności kulturowej i akceptowaniu kulturowej autonomii grup etnicznych. Z tym ostatnim związana jest retoryka swobód kulturalnych, autonomii, podtrzymywania języków ginących i wartości regionalnych wersji kultur etnicznych, którą się posługują i z której korzystają liderzy i organizacje etniczne. Kiedy jesienią 2000 roku upadł rząd S. Miloševicia ${ }^{19}$, Serbia weszła na drogę przemian demokratycznych, otworzyła się na zachodnie standardy, w efekcie wprowadzona została forma ochrony mniejszości etnicznych. Czynnik ten zaczyna oddziaływać intensywnie dopiero po rozpadzie Jugosławii, w której romańskojęzyczna ludność była niezauważana, ignorowana i utożsamiana z lokalną, regionalną zbiorowością wiejską. Jak mówią moi wlascy rozmówcy, w czasach jugosłowiańskich nie było łatwo być Wlachem. Skoro obecnie pojawia się w wywiadach sformułowanie: Dziś się nikt nie wstydzi tego, że jest Wlachem, oznacza to, że rozmówca odnosi się do przeszłości, gdy taki wstyd był faktem. W wywiadach pojawiają się aluzje do „trudności”, na które można było natrafić deklarując wlaską tożsamość. $Z$ wagi tego ostatniego czynnika zdają sobie sprawę liderzy wlascy. Jeden z nich otwarcie przypisuje swoją konwersję etniczną z serbskiej na wlaską właśnie pojawiającym się możliwościom działania grupy mniejszościowej w ramach rzeczywistości politycznej państwa serbskiego, której jeszcze w latach 80 . XX w. nie było. Twierdzi, że wprowadzenie europejskich standardów do polityki wewnętrznej Serbii zachęciło ludzi do otwartej deklaracji swojej tożsamości etnicznej. Zakłada, że wybory tożsamościowe mają podłoże w dużej mierze polityczne i tylko w pewnym stopniu wynikają z głębi utrwalonych przekonań. Poza tym, będąc społecznością graniczną, Wlasi mają świadomość, że pełnią w państwie serbskim ważną rolę w charakterze jego obrońców.

W wyniku działania tych głównych czynników można mówić we współczesnej wschodniej Serbii o trzech formach tożsamości wśród Wlachów. Wszystkie te kategorie w spisach mogą występować pod tą samą etykietą Wlasi, ale de facto ich forma tożsamości nie jest identyczna. Dotyczą one natomiast zawsze tych, którzy nie dokonali całkowitej i bezwzględnej konwersji narodowo/etnicznej, asymilując się świadomościowo z narodem serbskim. Są one wyrażane w postaci następujących poglądów:

1. Wlasi to grupa etnograficzna, zaznaczająca swoją specyfikę niektórych regionalnych cech kulturowych - grupa etnograficzna, regionalna w obrębie narodu serbskiego. Według tej koncepcji tożsamościowej Wlasi to Serbowie mówiący (zresztą coraz rzadziej) innym językiem, posiadający jedynie niektóre odmienne elementy folkloru. Przy tym grupą etnograficzną jest ta, którą wyróżniają badacze, a jej człon-

1924 września 2000 r. Slobodan Milošević przegrał wybory prezydenckie z Voislavem Koštunicą, jednak do października 2000 r. kwestionował wyniki wyborów. Ostatecznie 5 października uznał swoją przegraną. 
kowie niekoniecznie zauważają swoją specyfikę, i nie stanowi ona dla nich szczególnej wartości. W tej koncepcji obszar wschodniej Serbii jest regionem kraju, a jego ludność zdradza pewną odmienność o charakterze etnograficznym.

2. Drugi pogląd głosi, że Wlasi to odrębna grupa etniczna żyjąca na terytorium państwa serbskiego i uprawniona (i z uprawnień tych ostatnio korzystająca) do autonomii kulturowej: podtrzymywania własnego języka etnicznego i kulturowego dziedzictwa. Od 2003 r., gdy Wlasi wschodniej Serbii uzyskali status uznanej prawnie mniejszości, liderzy wlascy zaangażowali się w ruch etnicznego rozwoju kulturowego Wlachów jako grupy mniejszościowej w obrębie społeczeństwa Serbii. Wtedy powstał Vlaški Nacionalni Savet jako oficjalna reprezentacja w parlamencie krajowym.

Wlasi obu wymienionych opcji tożsamościowych nie wiążą swojej identyfikacji etnicznej z państwem rumuńskim, Rumunią jako krajem i nosicielem określonej narodowej kultury i językia. Podkreślają swoją polityczną lojalność wobec państwa serbskiego, Serbię traktując jako własną ojczyznę, zarazem nie negując oczywistych podobieństw języka wlaskiego do gwar olteńskich rumuńskich zbiorowości terytorialnie najbliższych. Niech przykładem będzie wypowiedź wlaskiego działacza z Zajeczaru, Dušana Firovića. Mówi on, że walczy o Wlachów, ale Jestem Wlachem, ale jestem Serbem! jestem Wlachem. Serb Wlach dla mnie to jest to samo. (16, DF), zapewne mając na myśli dwa aspekty tożsamości: kulturową i polityczną. Opowiada też że. Rumuni dlatego mieli do niego pretensję, gdyż powiedział, że Rumun $i$ Wlach to nie jest to samo (16 DF). Wśród osób o tej etnicznej tożsamości wlaskiej się też ci, którzy podkreślają związki kulturowe z Rumunią jako krajem, kulturowe pokrewieństwo z narodem rumuńskim, choć nie identyczność z nim. Stanowisko to nie znajduje jednak odzwierciedlenia w spisach powszechnych, gdyż osoby o tym typie tożsamości wybierają samookreślenie wlaskie, deklarując się jako Wlasi, a nie jako Rumuni. Czują niepodważalną bliskość z rumuńską kulturą, ale za swoją ojczyznę uznają Serbię, siebie w spisach nie nazywają nigdy Rumunami. Zapytani o polityczną przynależność, odpowiedzą (jak jeden z liderów Związku Wlachów w Zajeczarze), że jest Serbem i że Serbia, a nie Rumunia jest jego krajem. A nasza macierz ojczyzna to Serbia. (16 DF) Wiąże się to zwykle z ubolewaniem nad słabym zainteresowaniem państwa serbskiego Wlachami: Jednocześnie myślę, że Serbia najmniej robi dla swojej najmniejszej mniejszości. A to są Wlasi (16 DF) ${ }^{20}$.

3. Trzeci typ etnicznej/narodowej tożsamości reprezentują te osoby, statystycznie znacznie mniej liczne, które deklarują narodowość rumuńską, i uznają siebie za członków narodu rumuńskiego żyjących poza granicami rumuńskiego państwa. Używając etnonimu Wlach, siebie nazywając Wlachami, ale w sensie, który nadają temu słowu Rumuni. Podkreślają też, że autoetnonim w języku wlaskim (Romãn) wskazuje jed-

${ }^{20}$ Dejan Krstić z muzeum w Zajeczarze w ramach tej kategorii rozróżnia tych, którzy odmawiają pokrewieństwa z kulturą rumuńską Wlachom i tych, którzy ją podkreślają. Nie mam wątpliwości, że w tym zakresie mówić można raczej o kontinuum postaw niż o wyraźnym podziale, gdyż obydwie grupy deklarują się jako mniejszość, Wlasi w Serbii. 
noznacznie, że są Rumunami. Prorumuńscy Wlasi sa głośni, ale ocenia się liczbę ich jako niewielką. Osoby tej opcji tożsamościowej to najczęściej intelektualiści, z których duża część to studiujący w Rumunii, najczęściej medycynę, pobierający stypendia z racji swej rumuńskiej deklaracji narodowościowej. Wracają do Serbii z już ukształtowaną świadomością, że są na pewno Rumunami, którzy mieszkają za granicą jako rumuńska mniejszość narodowa. Dušan Prvulović jest jednym z liderów tej opcji tożsamościowej. Jak twierdzi, podczas wywiadu przed kamerą powiedział: Jestem Wlachem, ale dobrze bytoby żebym byt Rumunem. Posiada bliskie kontakty z konsulem rumuńskim, co sam mocno akcentuje (16 DP). Wśród szeregowych mieszkańców wiosek wlaskich opcja rumuńska bywa dość płynna lub częściej odrzucana. Zdarza się, jak w wiosce Mokrane, bez wątpienia wlaskiej, że towarzyszący mi prorumuński działacz wlaski stwierdza, że tu mieszkaja Rumuni, a miejscowy pasterz, przechodzący drogą ze zwierzętami poprawia go, mówiąc, że $w$ wiosce mieszkają Wlasi. Tę płynność dobrze charakteryzuje wypowiedź Dušana Firovicia, który mówi zapędzając się: vorbim limba rumeniaszczie (mówimy językiem rumuńskim) i poprawia się: vorbesk limba vlaszaszczie (mówię językiem wlaskim). Użycie tych dwóch słów wymiennie u tego lidera jest odruchowe, a nie ideologiczne, gdyż zdecydowanie zaliczyłabym jego stanowisko do drugiej z wymienionych kategorii tożsamościowych. Kiedy zdecydowany ideolog koncepcji prorumuńskiej w Negotinie przypomina z dumą, że żona Josipa Brosa Tity była Wlaszką, nie mówi, że była Rumunką; byłoby to dwuznaczne (16 DD). W różnych tego typu wypowiedziach termin Wlach ma sens raczej regionalny niż narodowy. Regionalizm jest nawet dla ideologów prorumuńskich bardzo ważny. Pojawia się wśród nich opinia, że Serbowie z tzw. Dynarskiej zony są inni niż Serbowie z wschodniej Serbii, żyjący razem z Wlachami. Stąd małżeństwa serbskowlaskie są tu, jak się thumaczy, wyjątkowo częste i absolutnie akceptowane.

\section{WLASKA TOŻSAMOŚĆ W DZIAŁANIU}

Tożsamość Wlachów serbskich jest bardzo płynna, potrafią ją w ciągu życia zmieniać. O innym ważnym liderze wlaskim orientacji pro-wlaskiej, tu wymienionej jako druga, z Boru, mówi serbski badacz wschodnioserbskich stosunków etnicznych, że do niedawna był prorumuński, a teraz zmienia się na prowlaskiego, bo to jest nowa ciekawa idea (16 DK). Podobnie o swojej osobistej konwersji etnicznej otwarcie opowiada Dušan Firović mówi, że ma 65 lat i do 60. roku życia określał się jako Serb, był liczony w spisach jako Serb, a cztery lata temu został przewodniczącym mniejszości wlaskiej. I pomyślatem, że jeśli moja babka i prababka mówiła po wlasku, skoro sq możliwości rozwijania tego bogactwa, tego piękna, tej tożsamości, tej muzyki, tej kultury... (16 DF)

W „sprawę wlaską" zaangażował się głęboko podczas spisu powszechnego w 2011 r. Opowiada o wysiłku, który trzeba było włożyć w taki a nie inny wynik spisu powszechnego; była to pracochłonna agitacja. Opowiada o tym, jak kilka lat temu 
objeżdżał ze zwolennikami wszystkie wsie, jak zbierali głosy, żeby stworzyć organizację i teraz ona jest. Namawiali do uczestnictwa w spisie i żeby deklarowali swoją prawdziwą narodowość. Tłumaczy, że tylko w ten sposób można było dostać prawa mniejszości narodowej. Można wnioskować, że ludność wlaska nie była ani aktywna, ani chętna do działania - nie była etnicznie zmobilizowana. w wyniku działalności Firovicia - jak się obecnie chwali - w spisie ponad 35 tys. Wlachów i tylko 2.5 tys. Rumunów zadeklarowało się na tym obszarze. W efekcie mogła być prawnie uznana etniczna mniejszość wlaska, a oficjalnie zaczęła działać Narodowa Rada Wlachów (Nacionalni Savet Vlaha). Dzięki temu z budżetu państwa przelewane są pieniądze na potrzeby mniejszości wlaskiej. Inicjatorzy i aktywiści wlascy są dumni, że udało się doprowadzić Wlachów po raz pierwszy w historii do statusu prawnie uznanej mniejszości etnicznej.

\section{EMBLEMATY ETNICZNOŚCI WLASKIEJ}

W gruncie rzeczy we wszystkich trzech typach opcji tożsamościowych pojawiają się te same symbole etniczne. Emblematami wlaskiej tożsamości są: kultura materialna, niematerialne aspekty kultury artystycznej, wyobrażenia o historii zamieszkiwanego obszaru, specyfika pewnych koncepcji wspólnoty, praktykowanie magii .

1. Odrębność specyficznych cech kultury materialnej takich jak stroje ludowe, ozdoby, wzornictwo, folklor. Wszyscy Wlasi, u których gościłam w domu, wiedząc, że interesuję się wlaską kulturą, wyciągali z szaf i skrzyń właśnie suknie, buty, skarpety, czapki i inne elementy ubioru, zawsze określane jako typowo wlaskie. Podtrzymują tę wizję wlaskiej odrębności kulturowej muzea, które prezentują te same elementy kultury materialnej jako markery odrębności etnicznej. Zapytany o to co chcą zachować Wlasi, burmistrz Majdanpeku odpowiada: Tradycje, język i miejsca, terytorium, pola $i$ wioski, gdzie pracujemy i żyjemy. $(16,57)$.

2. Ekspresja artystyczna w postaci form muzycznych, ludowej literatury epickiej. O wlaskiej muzyce wszyscy Wlasi mówią z dumą jako nie tylko odrębnej, ale też powszechnie lubianej, docenianej, zdobywającej uznanie ekspertów. Ten wysoki poziom tłumaczą ogromnym wkładem pracy i pieniędzy, przysyłanych przez wlaskich emigrantów do krajów Zachodniej Europy, z przeznaczeniem na kształcenie zespołów i solistów. Moi wlascy rozmówcy podkreślają, że właśnie Wlasi częściej zachowują formy artystyczne własnej kultury i że są bardziej od Serbów aktywni w zespołach ludowych. Wynika to, według nich, stąd, że stanowią liczebną większość w lokalnych zbiorowościach i że czują się tu bardziej autochtonami niż Serbowie.

3. Autochtoniczność i zakorzenienie historyczne. Jednym z elementów budujących tożsamość wlaską, pojawiającym się raczej u osób z wyższym wykształce- 
niem, jest polityczna historia Wlachów, wiążąca się z zamieszkiwanym dziś terytorium. Jak informuje mnie z satysfakcją wlaski działacz z Negotinu, od XVI wieku do 1833 na tych obszarach koło Negotinu istniała autonomia wlaska, rządzili wlascy książęta rodziny Karapandzić. Rozmówca odwołuje się do względnej autonomii Wlachów w okresie gdy teren ten należał do widinskiego sandżaku w administracji osmańskiej. Mówi o pierwotnej wlaskiej własności tej ziemi. Dużo później, jak przekonuje, zgodzono się na zakładanie tu wsi serbskim uchodźcom. Rozmówca podkreśla, że dopiero od 1833 Wlasi mają do czynienia na tym terenie z władzą serbską, tym samym akcentuje nie odwieczny związek tego obszaru z Serbią. W relacjach historycznych wraca się też do Wlachobułgarskiego cesarstwa, w którym Wlasi mieli ważny udział we władzy. Na taką interpretację historii obszaru bardzo nerwowo reagują historycy serbscy.

4. Odmienność niektórych instytucji społecznych - specyfika niektórych obyczajów i idei. Jest to odmienne rozumienie instytucji slavy, czyli więzi wspólnotowej, opartej na imieniu określonego patrona. Dla Serbów slava wiąże się z rodem, wielką, wielopokoleniową rodziną i przodkami, natomiast dla Wlachów kojarzy się z miejscem, z domem. W tym kontekście jest zrozumiałe, że wlascy emigranci zarobkowi, którzy już w trzecim lub czwartym pokoleniu pozostają poza krajem, budują w rodzinnych wsiach wielkie domy, widząc w nich zakorzenienie swojej slavy, swojego patrona. Dla Wlacha slava zawsze będzie związana z określonym miejscem, rodzinną wsią; znika wtedy gdy całkowitemu zapomnieniu ulega ten element kulturowy. Wlasi mówią o Serbach, że pozostawione w rodzinnych wsiach domy porzucają bezpowrotnie, gdyż symbolika ta nie ma dla nich znaczenia.

5. Magia. Jedną z cech przypisywanych Wlachom przez Serbów i Arumunów, ale również czasem wymienianą jako rodzaj etnicznego markera przez samych Wlachów są wierzenia i praktyki, określane w sumie jako magia. Przytaczane są przykłady odwoływania się do czarów, które ktoś wykonat przeciwko komuś innemu, praktyk, które miały komuś zaszkodzić lub pomóc. U rozmówców arumuńskich pojawiają się opowieści o magii najzupełniej współczesnej. Podczas amerykańskiej wojny (chodzi o bombardowania NATO w Jugosławii w 1999 roku - EN) ludzie w rozpaczy i poczuciu bezsilności powracali do magicznych praktyk, co oznacza, że ciagle w nie wie$r z y l i$, mówi profesor prawa na uniwersytecie w Niszu, podkreślająca swoje arumuńskie pochodzenie (M 2016). Jednak zarówno wśród naukowców serbskich, liderów wlaskich, jak i intelektualistów arumuńskich pojawia się zdecydowane twierdzenie, że magiczny światopogląd Wlachów to mit, który przedstawia ich w oczach świata w złym świetle, jako ludność zacofaną, niewykształconą, nie nadążającą za postępem. Starsza Wlaszką z Negotina opowiada szczegółowo o magicznych obrzędach w swojej rodzinie. Na to nerwowo reaguje Dušan Prvulović, wlaski intelektualista orientacji prorumuńskiej. Podważa opowiastki o wlaskiej magii, które w jego opinii są skwapliwie wykorzystywane przez dziennikarzy stanowiąc dla nich łakomy kąsek. . Atakuje powszechne przypisywanie Wlachom wierzeń i praktyk magicznych przez 
osoby, które w ogóle nie wiedzą kim są Wlasi. Patrzy się na nich jak na jakichś dzikusów. W tym narodzie jest dużo rzeczy ważnych, dobrych-śpiewacy, muzyka, kultura, a nie magia. (DP 2016). W innej rozmowie tę opinię wlaskiego intelektualisty potwierdza serbski etnolog z muzeum w Zajeczarze.

Wśród zwyczajów pogrzebowych Wlachów zwracają uwagę archaiczne znaki na nagrobkach przypominające indyjski (staroindoeuropejski) znak swastyki, czasem odwróconej. Znaki te pojawiają się w okresie do początku lat 40. ubiegłego stulecia; gdyż jego użycie przez niemieckich okupantów zniechęciło dawnych użytkowników. Od siedemdziesięciu lat znak ten w ogóle się nie pojawia. Poza tym współcześnie w wielu wsiach na cmentarzach często występują pewne specyficzne elementy nagrobków; budowane są przeszklone domki, rodzaj zamkniętych altan, w których odbywają się rodzinne spotkania wypominkowe. W niektórych wsiach, jak np. Jabłkovac, w takich domkach zobaczyć można stół, krzesła, kwiaty w wazonie, portret zmarłego. Te elementy cmentarnej architektury nie są jednak przez wlaskich rozmówców przedstawiane jako osobliwość ich kultury etnicznej.

6. Język. W wypowiedziach osób reprezentujących wszystkie wyróżnione trzy typy tożsamości Wlachów pojawia się wartość etnicznego języka, choć jego koncepcja bywa rozmaita. Powszechnie obecna jest idea nauczania języka etnicznego w szkole; jednakże nie zawsze chodzi o ten sam język. Zwolennicy drugiej opcji tożsamościowej mają na myśli naukę wlaskiego dialektu używanego we wschodniej Serbii. Jest to język lokalnie zróżnicowany, gwarowy, do niedawna nie znający skodyfikowanej formy pisanej.

Wspomina się inicjatora nauczania języka wlaskiego w szkołach, ***Jona Iljicia Daskole*, urodzonego w Brestovacu (dziś przedmieście Boru) w 1870 roku, zmarłego w 1954, który był miejscowym nauczycielem bezskutecznie walczącym o język wlaski w szkołach,.

Natomiast dla osób deklarujących narodowość rumuńską, działania na rzecz kodyfikacji gwar wlaskich i tworzenie z nich języka literackiego jest pozbawione sensu. Ich zdaniem jedynie sensownym rozwiązaniem jest nauczanie języka rumuńskiego, od dawna zestandaryzowanego i funkcjonującego jako literacki język państwowy. Gwary wlaskie, ich zdaniem, powinny pozostać niepisanymi dialektami lokalnymi, nie pretendującymi do statusu języka literackiego. Za absurdalne uznają drukowanie podręcznika języka gwarowego, podczas gdy już istnieje ukształtowany język literacki (D.P. 2016, Negotin).

Prorumuńskie partie są za wprowadzeniem do szkół języka rumuńskiego, zaś te prowlaskie - lokalnego dialektu. Jednak w gruncie rzeczy ani jedno ani drugie rozwiązanie nie przyjęło się $\mathrm{w}$ praktyce.

W roku 2014, staraniem wlaskiego lidera z Zajeczaru, Dušana Firovića opublikowany został podręcznik dla dzieci do nauki skodyfikowanego języka wlaskiego. Od roku szkolnego 2015-2016 8 km na południe od Zajeczaru, we wsi carańskiej Grljan, (gdzie ok. 200 dzieci uczy się w szkole ośmioklasowej), 49 uczniów uczęszcza na 
lekcje wlaskiego w trzech oddziałach. Nauczycielka wlaskiego, paradoksalnie, sama nie jest Wlaszką; wiele lat temu przybyła z Bośni i nauczyła się wlaskiego jako żona lokalnego Wlacha. Swoje dzieci stara się uczyć języka ojca, sama język znając z codziennej praktyki. Jak mówi dyrektorka szkoły, inne cztery nauczycielki uczęszczały na specjalne seminarium, finansowane ze środków Unii Europejskiej, bo one znaty język wlaski, ale musiały mieć certyfikat nauczyciela. (2016 DF). W szkole podstawowej w Grljanie pierwszym językiem obcym jest angielski, drugim włoski. Lekcje wlaskiego są nadobowiązkowe. Nauczycielka angielskiego informuje, że nie wszystkie chodzq na rumuński i poprawia się natychmiast: wlaski. Ten rodzaj przejęzyczenia spotyka się w wioskach wschodniej Serbii nagminnie, co świadczy o odruchowym identyfikowaniu wlaskiego z rumuńskim. Nauczyciele twierdzą, że potrzeba psychologiczna dziecka decyduje o tym, że się ono wlaskiego uczy, natomiast rodzice zawsze się na to godza. Stwarza to wrażenie, że uczenie dzieci w szkole języka etnicznego, obecnie zapominanego w młodym pokoleniu, jest dla większości działaniem najzupełniej naturalnym.

Dušan Prvulović, zwolennik rumuńskiej tożsamości narodowej serbskich Wlachów, ma jednoznaczny stosunek zarówno do nauczania jak i do tworzenia podręczników do języka wlaskiego. W 2015 dwaj wlascy działacze: Dragomir Dragić i Dušan Prvulović zorganizowali grupę wlaskich intelektualistów, którzy protestowali wobec drukowania podręcznika języka wlaskiego, opartego na lokalnej gwarze. Argumentowali, że nie można wymyślać języka. Prvulović podczas wywiadu uzasadniał swoje stanowisko: Austriacy nie mówia po austriacku, ale po niemiecku, Amerykanie nie mówia po amerykańsku ale po angielsku. Tak Wlasi nie mówia po wlasku ale po rumuńsku. Zdecydowanie się przeciwstawia tworzeniu pisanego języka na podstawie gwary: język mówiony to nie pisany. Atakuje te pomysły: Kto daje licencje na ten język, jaka katedra? Gdzie sa ci profesorowie? One się tworza w polityce. Ironizuje, że specjaliści, nie profesorowie, ale byle kto ma decydować na ulicy o formie języka, podkreśla, że nigdzie na świecie tak się nie tworzy języka przez pytanie ludzi na ulicy. Prvulović dodaje również Nie można się ciagle zajmować tym, że nie jesteśmy Rumunami tylko Wlachami. Trzeba szukać tego co nas zbliża, a nie ciagle mówić gdzie jest różnica, gdzie jest różnica. Powtarza, że standaryzacja języka w takiej postaci jak to robią Firović i jego koledzy nie ma sensu. Tu jest już gotowa forma języka - literacki rumuński. Nie trzeba niczego tworzyć. Rada Europy wspiera vlaski gowor, gwarę, w gwarze się mówi i stucha a nie pisze" (Prvulović 2016). W rzeczywistości oprócz języka wlaskiego w szkołach wschodniej Serbii bywa też nauczany rumuński. Tak jest na przykład w Majdanpeku, gdzie oprócz miejscowej ludności wlaskiej żyją osoby z różnych stron dawnej Jugosławii, które przybyły tu do pracy w rozwijającym się przemyśle wydobywczym. Wprowadzenie języka wlaskiego lub rumuńskiego do nauczania szkolnego jest w obu przypadkach traktowane jako sposób zapobiegający upadkowi języka etnicznego.

Historia deklaracji znajomości i praktycznego używania języka wlaskiego wskazuje na znaczny spadek posługiwania się gwarami romańskojęzycznymi we wschod- 
niej Serbii. Wlascy liderzy ubolewają nad postępującą utratą znajomości języka ojczystego u młodszego pokolenia. Sprzyjają temu liczne małżeństwa mieszane.

Druga, znacznie mniej liczna grupa romańskojęzyczna, Arumuni (Cincarzy) znacznie rzadziej zauważają swoje związki językowe i kulturowe i genealogiczne z Rumunią i rumuńską kulturą niż Wlasi wschodniej Serbii. Wprawdzie dostrzegają fakt, że wszystkie trzy języki (arumuński, wlaski i rumuński) należą do jednej kategorii języków romańskich, ale swój, arumuński, zwykle nie używany i w rodzinach dawno zapomniany, uznają za zdecydowanie odrębny od rumuńskiego. Wśród Wlachów opinie na temat wzajemnego podobieństwa tych trzech języków są podzielone i wkomponowane w bardziej złożone koncepcje tożsamościowe.

\section{POLITYCZNE NAPIĘCIA POGRANICZA. MIĘDZYNARODOWY ASPEKT WYBORÓW TOŻSAMOŚCIOWYCH WŚRÓD WLACHÓW}

Jako obszar pograniczny wschodnia Serbia zawsze podlegała większym fluktuacjom nastrojów od centralnych części Serbii. W dziejach Wlachów, jak to dziś podkreślają wlascy liderzy, istniały okresy zwątpienia we władzę serbską. Należał do nich okres wyniszczenia po wojnach tureckich w 1878 i bułgarskich w 1883, kiedy to lokalna ludność podniosła bunt, dziś interpretowany w języku konfliktu etnicznego. W chwili obecnej stosunki między Serbią i Rumunią na terenach nad Dunajem mają charakter delikatny, a nawet drażliwy. Dyrektor muzeum w Niszu, Nebojsa Ozimić, sam się deklarujący jako Arumun, otwarcie twierdzi: Wlasi walcza o swój status niezależnego etnosu. Porównuje tworzenie nowej etniczności Wlachów z powstawaniem etniczności czarnogórskiej. Jest to dążenie do uzyskania wpływów w takich ciałach politycznych jak parlament. Prorumuńscy Wlasi zabiegali nawet o przyłączenie się do uznanej i funkcjonującej jeszcze od czasów Jugosławii Tity mniejszości rumuńskiej w Wojwodinie, ale bez powodzenia. Zapewne przyczyny odrzucenia miały charakter finansowy, musieliby się z Wlchami dzielić otrzymywaną jako mniejszość pomocą od władz Serbii. W 2003 r. powstała Narodowa Rada Wlachów (Nacionalni Savet Vlaha), niezależny od istniejącego już od dawna przedstawicielstwa mniejszości rumuńskiej w Serbii. To wielu Wlachów skłoniło do odejścia od pomysłu identyfikowania się z Rumunami i Rumunią, tworząc szansę odrębnego funkcjonowania wewnątrz państwa serbskiego. W wyborach Wlasi głosują głównie na ogólnoserbskie partie, nie na etniczne własne. W ten sposób akcentują de facto swoją więź z Serbią jako państwem. Znamienne jest, że na emigracji Wlasi wiążą się z klubami i innymi organizacjami społecznymi serbskimi, a nie z rumuńskimi. Jeśli chodzi o zachowania polityczne wewnątrz Serbii, to działają tam dwie partie posiadające w nazwie odniesienia etniczne: Vlaska Narodna Stranka o orientacji prorumuńskiej i Stranka Vlacha, partia regionalna reprezentująca antyrumuńską tendencję tożsamościową. O ile w życiu codziennym Wlasi rozróżniają wśród siebie Ungurianów i Caranów, o tyle na pozio- 
mie Stranki Vlacha tego rozróżnienia nie ma. W ten sposób partie polityczne działają integracyjnie - łączą Wlachów serbskich w jedną całość. Prorumuńska Vlaska Nacjonalna Stranka jako partia działająca w ramach politycznych struktur Serbii nie ma prawa przyjmować finansowego wsparcia z Rumunii, a jej działalność ogranicza się do terytorium serbskiego.

Co jakiś czas pojawiają się poważniejsze napięcia międzypaństwowe, dotyczące terenów wschodniej Serbii. W 1995 r. doszło do drastycznego konfliktu międzynarodowego w związku z tym, że Vlaska Nacjonalna Stranka ogłosiła, że pograniczne miasta, takie jak Doni Milanovac, Kladovo, są miastami rumuńskimi, co wywołało pretensje terytorialne po stronie Rumunii. Aspekt psychologiczny wzajemnych relacji międzypaństwowych jest skomplikowany i dynamiczny. Historyczne dzieje Rumunii i Serbii miały wpływ na relacje Wlachów z ludnością Rumunii. W czasach komunistycznych, gdy w Jugosławii był dużo wyższy poziom życia niż w Rumunii, należącej wtedy do bloku wschodniego, Wlasi serbscy mniej chętnie podkreślali swoją rumuńską przynależność kulturową. Ówczesne ubóstwo Rumunii nie zachęcało do zacieśniania związków kulturowych z tym krajem. To Rumuni uciekali przez Dunaj do Jugosławii aby pracować po stronie serbskiej jako biedni robotnicy i w Serbii byli postrzegani jako ubożsi krewni z komunistycznego państwa. Następnie, po rozpadzie Jugosławii losy się odwróciły: Wlasi zubożeli i sami masowo zaczęli wyjeżdżać na emigrację zarobkową do Austrii, Francji i Niemiec. Jeszcze do dziś bogaci Wlasi z obszaru wschodniej Serbii czują wyższość wobec biednych Rumunów, tych za Dunajem, którzy de facto są ich pobratymcami. Wstąpienie Rumunii do Unii Europejskiej w 2007 r. i tendencja do wstrzymania poszerzania Unii wpływa jednak na podniesienie statusu mieszkańców Rumunii w oczach Wlachów.

W Jugosławii nie było przeszkód w praktykowaniu tradycji folkloru wlaskiego, można nawet powiedzieć, że był popierany. Jednakże w serbskim radio wlaska muzyka zapowiadana była po serbsku, co wskazywało na hierarchiczny układ między oboma etnosami. Obecnie w rozmowach z lokalnymi Wlachami ciągle jest podkreślana wszechobecna serbska dominacja.

Jeszcze inną kwestią we wzajemnych relacjach serbsko-rumuńskich jest działalność rumuńskiej cerkwi prawosławnej na terenie wschodniej Serbii i pewien rodzaj konfliktu z prawosławną cerkwią serbską ${ }^{21}$. Rumuńska cerkiew wysyła prawosławnych duchownych w roli misjonarzy na serbskie tereny zamieszkałe przez Wlachów, wprowadzając do liturgii w lokalnych świątyniach język rumuński. Jednak, ponieważ w życiu społecznym Wlachów religia nie jest zbyt ważna, i nie religia ale język jest markerem etnicznym, rumuńska cerkiew z trudem zyskuje sobie zwolenników. Wlasi posługują się kalendarzem religijnym juliańskim, obowiązującym w Serbii, a w Rumuni cerkiew prawosławna przyjęła kalendarz gregoriański. Pojawiła się w związku z tym kłopotliwa rozbieżność. Rumuńscy duchowni złagodzili jednak swoje zasady i przyjęli na terenie Serbii kalendarz juliański. W Negotinie, w budynku poga-

\footnotetext{
${ }^{21}$ J. Petrović, Z. M. Jovanović, A Priest on the Border, Niš 2013.
} 
rażowym została zbudowana malutka, pięknie ozdobiona cerkiewka. Nabożeństwa odprawia w języku rumuńskim młody ksiądz z Rumunii. Konfliktowa sytuacja od lat trwa w związku z budową cerkwi w Malajnicy już od ponad dziesięciu lat. (W nabożeństwie odprawianym przez rumuńskiego duchownego po rumuńsku $\mathrm{w}$ - jak się potem okazało - niewyświęconej cerkwi - uczestniczyłam w lipcu 2007 r.) Bojan Aleksandrović, miejscowy duchowny (vikar), Wlach wyświęcony w cerkwi serbskiej, pozostający z nią w konflikcie, korzystając z funduszy cerkwi rumuńskiej, rozpoczął budowę cerkwi we wsi Malajnica na własnym prywatnym terenie. Jednak po ponad dziesięciu latach nie ma zgody państwa serbskiego na budowanie i wyświęcenie cerkwi rumuńskiej (wlaskiej). Do tej chwili trwa konflikt, a sprawa trafiła do Trybunału Sprawiedliwości w Strasburgu w wyniku starań Dušana Prvulovića, prowadzącego w Negotinie miejscowy oddział Organizacji Praw Człowieka (Human rights). Ponieważ władze serbskie nie godzą się na wyświęcenie cerkwi w Malajnicy, a budynek już stoi, projektuje się założenie tam żeńskiego klasztoru prawosławnego, ciągle żywiąc nadzieję, że się uda uzyskać zezwolenie kościelnych władz serbskich na wyświęcenie wlaskiej cerkwi. Tymczasem odprawia się nabożeństwa w języku wlaskim od czasu do czasu pod przydrożnym krzyżem, między wsiami Szipikowo i Aleksandrovac w pobliżu bułgarskiej granicy.

Dodać należy, że nie tylko dla liderów opcji prorumuńskiej jednym z zasadniczych punktów, wokół którego rozgrywa się albo cichy albo jawny konflikt jest cerkiew serbska, którą niektórzy wlascy liderzy uznają za najbardziej konserwatywny i niechętny Wlachom organ państwa serbskiego. Dzieje się tak, mimo że państwo jest z założenia świeckie. Wlasi prorumuńskiej orientacji tożsamościowej najgorszą opinię mają nie tyle o Serbach, co o serbskim kościele prawosławnym, w tym zwłaszcza o serbskich duchownych, którzy są, ich zdaniem, zorientowani wyjątkowo nacjonalistycznie. Moi rozmówcy tej opcji tożsamościowej twierdzą, że w kościele duchowni serbscy mówią o kwestiach politycznych, dotyczących państwa serbskiego, a nie o sprawach duchowych, boskich. Zarazem nie tolerują specyfiki etnicznej wyznawców, własnych wlaskich parafian. Badaczowi opowiadane są przykłady sytuacji, gdy małżeństwo mieszane zgodnie wyraża życzenie żeby podczas różnych rodzinnych ceremonii uwzględniany był również język wlaski. Na to nie wyrażają zgody duchowni serbscy. W serbskim klasztorze koło Negotinu mam okazję być świadkiem dyskusji między prorumuńskim wlaskim intelektualistą i serbskim mnichem. Pierwszy mówi, że powinny być w kościele uwzględniane elementy wlaskiej kultury regionalnej. Mnich odpowiada, że polityka nie może się mieszać do spraw religijnych $(16 \mathrm{~N})$.

Jeszcze inną kwestią, związaną z bliskością terytorialną i kulturowym podobieństwem Wlachów i pobliskiej Rumunii jest problem historycznego pochodzenia ludności wlaskiej we wschodniej Serbii. Obecnie, w muzeach historycznych regionu Negotina, w ogóle nie pojawia się tematyka pochodzenia miejscowej ludności wlaskiej, jej genezy. Nikt nie wypowiada się czy jest jakaś ciągłość w zaludnieniu od starożytności, czy też są jakieś luki w zasiedleniu, jaką rolę w kompozycji ludności odegrali Rzymianie i wcześniejsi Celtowie, Trakowie, Dakowie. Nawet wybitny 
miejscowy archeolog zdecydowanie odmawia informacji, a nawet nie chce się dzielić swoimi domysłami na ten temat. Sprawa jest drażliwa, dotyka ważnych argumentacji politycznych. Rumuńska nauka i polityka upiera się przy koncepcji pochodzenia wszystkich Wlachów we wschodniej Serbii z obszaru dzisiejszej Rumunii. W ten sposób dowodzi się rumuńskiej przynależności narodowej Wlachów. Jest to temat delikatny, który może psuć w zasadzie poprawne stosunki Serbii i Rumunii podobnie, jak w przeszłości psuł stosunki rumuńsko-greckie. ${ }^{22}$

W historii Rumunii od zarania istnienia państwa stosunek do grup romańskojęzycznych na Bałkanach był jednoznaczny: miały to być grupy Rumunów żyjących poza granicami Rumunii, w Grecji, Albanii, Serbii, które należało wspierać i wpajać im tożsamość rumuńską. W szczególnie intensywny sposób dotyczy to romańskojęzycznych Wlachów, mieszkających tuż za granicą, za Dunajem, we wschodniej Serbii. Rumuńska koncepcja pochodzenia całej ludności Bałkanów, w tym serbskich Wlachów oddziałuje na podziały tożsamościowe wśród ludności wlaskiej. WNegotinie żyje grupa Wlachów, którzy przypisują sobie tożsamość narodową rumuńską. Grupy prowlaskie i prorumuńskie wzajemnie się oskarżają o przekupność, branie pieniędzy od Rumunii. Postawa prorumuńska jest krytykowana też z innych względów, gdyż w ten sposób człowiek pozbawia się w ogóle narodowości: wśród Wlachów nie jest swoim i wśród Rumunów także. Przeciwnicy opcji prorumuńskiej podkreślają, że Wlasi to największa mniejszość etniczna w Serbii. Oddziaływania Rumunii dotyczą także języka etnicznego, którego wlaskie organizacje chcą uczyć w szkołach we wsiach wlaskich. Dušan Firović, inicjator nauczania wlaskiego, opowiada jak konsul rumuński przyszedł do szkoły w Grljanie i dziwił się, dlaczego tu nie ma żadnego dziecka rumuńskiego. Firović miał odpowiedzieć: Nie ma bo ich tu nie ma. Nie możecie ich zrobić. Opowiada się także o podobnych incydentach w Zajeczarze, gdzie tam istniejący rumuński konsulat zorganizował lekcje języka rumuńskiego dla dzieci z nielicznych małżeństw mieszanych, serbsko-rumuńskich, Nauczycielka angielskiego w szkole w Grljanie koło Zajeczaru, sama Wlaszka, w prostych słowach deklaruje: Wlasi nie sa Rumunami. Ich język nie jest ten sam. My nie jesteśmy tym samym ludem, my jesteśmy innym ludem. (16, Grljan). Lider wlaski z Boru ujmuje to podobnie: To, że wlaski jest bardzo podobny do rumuńskiego, że jest dialektem rumuńskiego, to nie znaczy, że my jesteśmy Rumunami.

Jak płynna, złożona i sytuacyjna jest tożsamość wlaska niech świadczy następująca wypowiedź Dušana Firovicia: Kiedy ja się ogłosiłem, że jestem Vlachem, Rumuni mnie oskarżyli, że przerabiam Vlachów na Serbów. A to nie jest prawda. Sprawa komplikuje się jeszcze dalej, gdy wlaska tożsamość okazuje się wyłącznie sprawą indywidualnego wyboru: Ale jeśli ktoś zechce się poczuć Vlachem bo na przykład kocha vlaska muzykę, kulturę, język, chce się go uczyć, my zapraszamy do naszej mniejszości. Jeśli chcesz być Vlachem, chcesz się tak deklarować, w porządku, jesteś Vlachem. (2016, Zajeczar). W tym samym duchu wypowiada się wlaski etnograf z Majdanpeku

\footnotetext{
${ }^{22}$ M. Tanty, Bałkany XX wieku, op. cit.
} 
twierdząc, że za Wlachów mogą być uważani nie tylko rdzenni Wlasi, ale i tacy, którzy 30, 40 lat mieszkają wśród Wlachów i czują z nimi związek, uczą się języka, obyczajów: To ona [wola ] łączy różnych ludzi. Jednak wywód się załamuje, gdy młody etnograf dodaje: $i$ maja slavę $e^{23}$. W tym ostatnim momencie obecny przy rozmowie szef lokalnego urzędu razem z moim rozmówcą, obydwaj Wlasi, wybuchają śmiechem. Najwyraźniej jest jakaś sprzeczność w tym, że się jest Wlachem z urodzenia i z wyboru. Właśnie takiej „dowolności” w wyborze tożsamości wlaskiej stanowczo i z irytacją przeciwstawia się główny lider opcji prorumuńskiej wraz ze swoimi młodszymi pomocnikami, wypowiadając się ironicznie: Każdy może być Vlachem... (2016, Negotin).

O ile ci, którzy deklarują odrębność i specyfikę wlaskiego etnosu są zarazem bliscy państwu i historii serbskiej, w przypadku osób zorientowanych tożsamościowo prorumuńsko jest odwrotnie. Tożsamościowa orientacja prorumuńska jest w ogromnym stopniu związana z polityczną opcją proeuropejską, a z idealizacją UE wiążą się oczekiwania istotnej pomocy finansowej. Wśród prorumuńskich Wlachów często zdarzają się osoby nastawione bardzo antyrosyjsko, ale też antyamerykańsko. Antyamerykańskość jednak bardziej zdecydowanie manifestuje się wśród zwolenników orientacji prowlaskiej, nastawionej na współpracę z Belgradem.

\section{WYBORY TOŻSAMOŚCIOWE I STOSUNEK DO PAŃSTWA SERBSKIEGO}

Wśród Wlachów deklarujących rumuńską narodowość nieustannie są wyrażane pretensję wobec państwa serbskiego, choć u zwolenników opcji prowlaskiej również spotykałam wypowiedzi krytyczne - narzekania na brak zainteresowania Wlachami wśród władz centralnych Serbii, na brak pomysłów ekonomicznych dotyczących zatrudnienia młodzieży, na zaniedbania gospodarcze. Z goryczą mówi się o władzach serbskich, które nie doceniają wkładu Wlachów w walki niepodległościowe Serbii, zarówno w czasie wojen bałkańskich jak i, pierwszej i drugiej wojny światowej. Pokazuje się z dumą lecz zarazem goryczą pomniki żołnierzy, którzy zginęli w tych wojnach, wskazując na przewagę nazwisk wlaskich na tablicach pamiątkowych. Zgłasza się też gorzką pretensję do „fasadowego" charakteru centralnej instytucji Narodowej Rady Wlachów, przypomina się, że jej przewodniczącym został człowiek, o którym mówi się, że jednego stowa nie zna po vlasku.

\footnotetext{
${ }^{23}$ Slava to typowo serbskie święto, upamiętniające świętego, patrona rodziny.
} 


\section{PODSUMOWANIE \\ NOWA ETNICZNOŚĆ - NOWY REGIONALIZM}

Przypadek rozwoju sytuacji kulturowej na terenie wschodniej Serbii wskazuje na pewien globalny kierunek przeobrażeń, który można podsumować słowami: od etniczności nawykowej do intencjonalnej. Kulturowe formy, które jeszcze do niedawna funkcjonowały w zbiorowościach zamkniętych na kontakty społeczne, opierały się na międzypokoleniowym przekazie rodzinnym. Obecnie etniczność zostaje uwikłana w ruchy ideologiczne i sformalizowane instytucje i wydarzenia polityczne. Te przeobrażenia wiążą się z przemianami form międzypokoleniowego przekazu kulturowego, który już w coraz mniejszym stopniu opiera się na transmisji wewnątrzrodzinnej. Znaczenia nabierają imprezy publiczne, sterowane i organizowane przez instytucje. Ogólnoświatowa moda na festiwale etniczne i regionalne wpływa na zainteresowanie odrębnościami kulturowymi, w tym także dotyczącymi grup bezpaństwowych. Dzięki niej poszerza się wiedza o kulturze wlaskiej, jej specyfice, jej pięknie i atrakcyjności. Zjawisko to może $\mathrm{z}$ jednej strony grozić obniżeniem wartości elementu etnicznego, grożąc przemianą więzi etnicznej w regionalną. $Z$ drugiej strony może też spowodować wzmocnienie etniczności grupy przez wytworzenie takiej jej formy kulturowej, która znajdzie właściwe, dogodne, a nawet atrakcyjne miejsce we współczesnym świecie. To ostatnie dokonuje się drogą adaptacji dawnych form kulturowych do współczesnych wymogów i zainteresowań wszystkich pokoleń. Festiwale etnokulturowe oddziałują na wzmożenie zainteresowania tradycyjnymi formami ekspresji artystycznej Wlachów zarówno w środowiskach zewnętrznych, jak i wśród samych Wlachów. Stanowią zarówno formę podtrzymania jak i kreowania nowej etnicznej kultury ludowej. Odbywa się to $\mathrm{w}$ duchu kreowania i zarazem popierania tradycyjnej kultury wlaskiej. ${ }^{24}$ Festiwale wpływają mobilizująco na społeczności lokalne, prowokując inwencyjność i kreatywność w twórczości folklorystycznej. Na wlaskich festiwalach folklorystycznych każda wieś przedstawia swój własny program. Nie wynika to z faktu, że poszczególne wsie od dawna między sobą różnią się, różnorodność tworzy się wtórnie. Prowadzi to do nowego zróżnicowania lokalnego, skutkując głębokimi zmianami kultury etnicznej Wlachów, opartej obecnie przede wszystkim na folklorze. $Z$ drugiej strony proces ten oddziałuje na wlaską mobilizację etniczną, utrwalenie czy nawet na odnowę poczucia tożsamości etnicznej. Młodzi Wlasi, jak podkreślają starsi, prawie w ogóle nie znają języka wlaskiego: czasami słabo mówią, albo w ogóle nie mówia, nie znaja etnicznej czy lokalnej tradycji $(16,56)$. Obecnie dla młodych Wlachów niezwykle ważne okazuje się to, co zobaczą na scenie, gdyż zobaczą to po raz pierwszy w życiu. Długi okres unifikującej polityki etnicznej Jugosławii Tity sprzyjał zanikowi języka etnicznego i etnicznego folkloru. Młody wlaski intelektualista z Majdanpeku tłumaczy, że gdy był uczniem w szkole obowiązywał tylko język

${ }^{24}$ Jak powiedział pewien podhalański nauczyciel, Góral, jego hasłem jest kreować tradycję góralska i ja popierać. 
serbski, a mieszanie serbskiego z wlaskim było traktowane jako brak wykształcenia, rodzaj zacofania. Prowadziło to do powstania przerwy w komunikacji międzygeneracyjnej w zakresie przekazu etnicznej kompetencji kulturowej. W chwili obecnej program występu każdego lokalnego zespołu artystycznego, określanego jako ludowy, przygotowuje ekspert - specjalista artysta, który dobrze zna tradycje, dobrze zna kulturę w jej wersji historycznej, posiada wiedzę specjalistyczną w tym zakresie. Dziś pokolenie osób znających elementy głębszej tradycji muzycznej, epickiej Wlachów wymiera. Siłą rzeczy pokolenie to w coraz mniejszym stopniu pełni rolę w procesie międzypokoleniowego przekazu kulturowego. Rolę tę w coraz większym stopniu przejmują eksperci od folkloru - znawcy, profesjonaliści: etnografowie, muzykolodzy, choreografowie.

Zanik używania w życiu codziennym, a także w sytuacjach publicznych języka wlaskiego bywa czasem traktowany jako wskaźnik dramatycznego końca etnosu. Spotykałam też inne opinie. Są tacy, którzy sugerują, że język, a także jego utrata nie decyduje o trwaniu czy utracie tożsamości narodowej. Niektóre narody przejęły cudzy język, inne mają język bardzo podobny do sąsiadów $(15,28)$. Utratę stopniową języka etnicznego tłumaczy się wśród Wlachów z jednej strony procesami globalizacyjnymi, a z drugiej polityką społeczną państwa serbskiego. Nie ma natomiast wątpliwości, że procesy kulturowe nie pozostają bez wpływu na kształt tożsamości etnicznej Wlachów wschodniej Serbii. Współczesna forma wlaskiej tożsamości może przybierać dwie postaci: można być zarazem Wlachem i być Serbem, można też serbską tożsamość negować deklarując przynależność do narodu rumuńskiego. W odpowiedzi na pytanie o tożsamość narodową można usłyszeć: Jestem Serbem, ale jestem Wlachem. Nie są to konfliktowe tożsamości, gdyż opierają się na odrębnych podstawach, inny sens ma bycie Wlachem, a inny bycie Serbem. Jedna warstwa tożsamości ma sens lokalny, regionalny, kulturowy, a druga polityczny i edukacyjny. Ważnym elementem rzeczywistości wschodniej Serbii są bardzo liczne małżeństwa między Wlachami i Serbami, pochodzącymi z różnych republik jugosłowiańskich. Ludzie o takim „mieszanym” pochodzeniu etnicznym natrafiają w życiu na problem wyboru tożsamości własnej. Wśród aktywistów zaangażowanych we wlaski ruch etniczny spotykałam bardzo często osoby o takim właśnie pochodzeniu, a czasem posiadający współmałżonków nie-wlaskiego pochodzenia. W sytuacji dzieci z etnicznie mieszanych małżeństw zawsze dochodzi do indywidualnego wyboru tożsamości narodowej. Na przykład, działacz wlaski o wyrazistej wlaskiej tożsamości w Majdanpeku, mimo że jego matka jest Bośniaczką, a ojciec lokalnym Wlachem, podkreśla, że zawsze czuł się Wlachem i deklarował tę tożsamość. Natomiast jego rodzona siostra czuje się Serbką $(16,55)$. W rozmowach, wywiadach, na spotkaniach partii politycznych Wlachów pojawiają się słowa dramatyczne; są to narzekania na marginalną pozycję Wlachów w Serbii - nie należą do kultury serbskiej, ale też nie są Rumunami, żyją na pograniczu państw i kultur i znikąd nie mogą oczekiwać pomocy. 


\section{BIBLIOGRAFIA}

Adamczuk Lucjan, Łodziński Sławomir, Mniejszości narodowe w Polsce w świetle Narodowego Spisu Powszechnego z 2002 roku. Warszawa 2006.

Barth Fredrik, Ethnic Groups and Boundaries, Boston 1969.

Koseski Adam, Batkańskie konflikty etniczne na przełomie XX i XXI stulecia, w: Batkany. Etnokulturowe podtoże konfliktów, red. W. Konarski, A. Koseski, Warszawa 2006, s. 93-120.

Luković Miloš, Sezonowe migracje pasterzy na Bałkanach: charakter, historia, transformacje, „Res Historica", 2016, nr 40.

Łodziński Sławomir, Etniczność i jej miary. Przypadek pytań „etnicznych” w Narodowym Spisie Powszechnym Ludności w Polsce w 2011 roku, w: Antropologiczne inspiracje. Księga Jubileuszowa dla profesor Ewy Nowickiej, Warszawa 2013, s. 161-179.

Łodziński, Sławomir, Warmińska Katarzyna, Gudaszewski Grzegorz, Szmeja Maria, Mniejszości narodowe $i$ etniczne w Polsce w świetle Narodowego Spisu Powszechnego Ludności z 2011 roku Warszawa 2015.

Markus Hazel, Self-schemata and processing information about the self, „Journal of Personality and Social Psychology", 1977 t. 35, s. 63-78.

Nowicka Ewa, Swojskość i obcość jako kategorie analizy socjologicznej, w: Swoi i obcy, red. E. Nowicka, Warszawa 1990.

Popović Dušan, O cincarima: prilozi pitanju postanka naseg gradanskog drustva, Beograd 1937.

Tanty Mieczysław, Bałkany XX wieku. Dzieje polityczne, Warszawa 2003.

Ustawa o ochronie praw i wolności mniejszości narodowych, Устав Републике Србије. 2006, http:// www.parlament.gov.rs/upload/documents/Ustav_Srbije_pdf.pdf [dostęp 03.07.2018]. 